\title{
Improving Learning Activities and Outcomes of Students by Application of Observation-based Learning
}

\author{
Nurlaelah $^{1, *}$, Akhmad Syahid ${ }^{1}$, Muhammad Ikram Nur Fuady², Mega Fia Lestari ${ }^{3}$ \\ ${ }^{1}$ Department of Madrasah Ibtidaiyah Teacher Education, Universitas Muslim Indonesia, Urip Sumoharjo, 90231, Makassar, Indonesia \\ ${ }^{2}$ Department of Law, Universitas Islam Negeri Alauddin Makassar, Romang Polong, 90221, Gowa, Indonesia \\ ${ }^{3}$ Department of Chemical Analysis, Akademi Komunitas Industri Manufaktur Bantaeng, Nipa-Nipa, 92461, Bantaeng, Indonesia
}

Received December 13, 2020; Revised January 28, 2021; Accepted February 24, 2021

\section{Cite This Paper in the following Citation Styles}

(a): [1] Nurlaelah, Akhmad Syahid, Muhammad Ikram Nur Fuady, Mega Fia Lestari , "Improving Learning Activities and Outcomes of Students by Application of Observation-based Learning," Universal Journal of Educational Research, Vol. 9, No. 3, pp. 479-486, 2021. DOI: 10.13189/ujer.2021.090307.

(b): Nurlaelah, Akhmad Syahid, Muhammad Ikram Nur Fuady, Mega Fia Lestari (2021). Improving Learning Activities and Outcomes of Students by Application of Observation-based Learning. Universal Journal of Educational Research, 9(3), 479-486. DOI: 10.13189/ujer.2021.090307.

Copyright $\mathrm{O} 2021$ by authors, all rights reserved. Authors agree that this article remains permanently open access under the terms of the Creative Commons Attribution License 4.0 International License

\begin{abstract}
Various studies on learning methods continue to develop a learning method that can increase students' enthusiasm for learning activities and outcomes. This research aimed to measure the increase in students' learning activities and outcomes using the Observation-Based Learning (OBL) method as a practical learning alternative. The research was a Classroom Action Research, and the subjects were the eighth-grade students of Madrasah Tsanawiyah Negeri (MTsN) 2 Makassar in English lesson. The procedure of this research was carried out in four cycles, namely planning, implementation, observation, and reflection. The research used quantitative and qualitative approaches by calculating the increase in students' learning activities and outcomes using the observation sheet, pre-test, and post-test. The results showed that the OBL method had an instructional and nurturing effect. This can be seen by observing curiosity, discipline, motivation, flexibility, and enthusiasm through the visual, oral, emotional, and mental activities. Besides, the OBL method was proven to shift the learning paradigm from subject-oriented and teacher-centered to student-centered. In this research, the designated learning method could be implemented well in English lessons in the eighth grade of MTsN 2 Makassar. This means that it can also be adopted in any other lessons or subjects from basic education to secondary education. Therefore, the OBL method has a significant impact on both teachers and students to create and even increase enthusiasm for learning activities and outcomes.
\end{abstract}

Keywords Learning Activities, Learning Outcomes, MTsN 2 Makassar, Observation-based Learning

\section{Introduction}

Education is a measure of a nation's progress with the goal of humanizing human beings. From the perspective of education, theories and practices are considered as essential and inseparable elements. Therefore, it is needed to change the learning paradigm from teacher-centered to student-centered [1]. Such paradigm should also be implemented in Generation Z, a generation born above the 2000s and accustomed to living with Information and Technology (IT) by browsing the internet, having various social media accounts, and utilizing gadgets. Today's era poses challenges to the so-called Generation $\mathrm{Z}$ to become smarter, more active, and more competitive, including those who reside in Indonesia as a developing country [2].

A study by the Programme for International Student Assessment (PISA) is routinely conducted by assessing 600,000 children aged 15 years from 79 countries every three years [3]. This study attempts to compare the mathematical, reading, and scientific performance of those children. For the reading performance, Indonesia has an average value of 371 . On the other hand, China is ranked first with an average score of 555, immediately followed by Singapore in the second place with an average score of 
549. As regards the performance of science and mathematics, Indonesia reaches an average of 396 and 379 respectively. These figures indicate that Indonesian students' interest in learning is relatively low, compared to its neighboring countries in the region of South East Asia, e.g. Singapore, Malaysia and Thailand.

As a consequence, a learning method that can increase students' enthusiasm for learning activities and outcomes is much needed [4]. The method in question should further be able to accommodate all aspects which are typically involved in the learning process, namely visual, aural, emotional, and mental aspects. Given a number of options, the researchers eventually felt interested in developing a method by observing the state of the students and the surrounding area since it has enormous potential to significantly affect the learning course process.

The advantage of the observation method is that students will participate actively in the thinking process, so their emotion will get involved in the learning process. This will indirectly allow them to improve skills through activities, observe processes or events independently, and enrich their experience and curiosity [5]. By employing the observation method, they will have a better understanding of abstract things and a longer memory for them.

On the other hand, a report by Trends in International Mathematics and Science Study (TIMSS) was made by examining the mastery of sciences of eighth-grade students from 39 countries, including Singapore, Taiwan, South Korea, Japan, Turkey, Malaysia, Thailand, Saudi Arabia, Morocco, and Indonesia [6]. The results of the report placed Indonesia below South Africa as the last country. However, Indonesia was not included in 39 countries in the report.

According to the report, Indonesian students' low interest in education can occur at all levels of education, from primary education and secondary education to higher education. The same condition also applies in both public and private schools as well as Islamic schools. What is quite suprising is that their high interest in the beginning of basic education often falls and even disappears on its way to the next level of education. In fact, the key to successful science studies is students' interest [7]. As a result, they only graduate and get a school diploma without interest in the learning.

Therefore, eighth-grade students in secondary education became the focus of the researchers in finding an alternative solution to increase their learning interest. The previous report was taken as the basis for the researchers to examine the eighth-grade students of an Islamic state junior high school or also known as Madrasah Tsanawiyah Negeri (MTsN) in an English lesson. A foreign language is salient in the era of globalization in order to achieve the national sovereignty [8]. In relation to this, English is often preferred in most educational institutions in Indonesia [9]. According to a study,
Indonesian students are left behind by other countries in terms of mastering the subject. This is caused by the the fact that the learning method of international students is by prioritizing observation (research) and creativity in a particular field, rather than merely by repeating and memorizing (rote learning method) [10]. The psychological conditions and creativity of students should also be taken into account. Besides, a conducive atmosphere will encourage students to study harder [11].

According to Dyers, learning procedures in the classroom can be assessed from several aspects, as summerized in 5M, namely Mengamati (observing), Menanya (Questioning), Mencoba (Experimenting), Menalar (Associating), and Membentuk Jejaring (Networking) [12]. Thus, it is necessary to formulate a learning-based curriculum that emphasizes personal experience through observing, asking, reasoning, and experimenting (Observation-Based Learning) as to increase students' creativity and learning outcomes. The curriculum also requires a new environment to create social constructivist in the classroom, thus enabling the learning to run well [13]. According to Ronna C. Turner (2017), OBL showed that observation is effective in improving the interest of students in mastering subjects in the learning process with an inquiry-based learning environment [14]. The presence of observation can also influence the creativity of visual and verbal arts for students [15]. In addition, observation has a constructive effect in increasing creative products, creative processes, and motivation of students in the art learning process [15]. Considering these advantages, the researchers were encouraged to conduct research on OBL.

Educational evaluation should be carried out to improve the quality of students [16]. Education follows an evolutionary process that occurs in life, particularly for those who attend Islamic schools [17]. In fact, a different learning can be introduced with a different model. Consequently, a model appears to be fundamental and should focus on students, teachers, and other aspects involved in the process and contribute to the development of people in the future [18]. In this regard, there is a tendency of students to imitate the behavior and actions of people around them [19].

A new learning method can be an effective alternative to increase students' learning activities and outcomes in English lesson, as well as identifying the inhibiting and supporting factors of the OBL method [20]. Thus, to implement a learning process, the creativity of students must be developed at their fullest extent. This is principally meant to make them feel comfortable and enthusiastic in learning [21]. The OBL method can then help to shift the perception from teacher-centered to student-centered, which is obviously part of the evolution in education [22]. Furthermore, the OBL method will help in the development of the behavior of students dwelling in cities to a better direction [23]. 
Therefore, a new comprehensive learning method is needed, considering that English lesson is prioritized in Islamic schools [24]. Students in such schools should not be left behind in terms of education. Because a learning method that can accommodate the interest of all stakeholders, including students, teachers, education staff, and others, becomes neccessary in all levels of education [25]. It futher requires a broad concept and a guaranteed validity. In this case, the researchers would conduct research into an effective and efficient learning method.

The purpose of the OBL method is to provide an effective learning alternative for increasing learning activities and outcomes of students at MTsN 2 Makassar. The questions arising from this research lies in how the OBL method improves the learning activities and outcomes of the students and what are the inhibiting and supporting factors of the OBL method.

\section{Methods}

This research was a Classroom Action Research with the subjects being the eighth-grade students of MTsN 2 Makassar in English lesson [26]. The data of the research were analyzed using quantitative and qualitative approaches [27]. The results of the OBL method obtained from the teaching and learning process were interpreted to teach the subject by inviting students to observe objects [28]. The quantitative approach was used to compare changes that occured in the pre-test and post-test given with the sheet of the same questions, while the qualitative approach was intended to observe the needs and responses of the subjects through the observation in class. This research was carried out by following the procedure of Classroom Action Research with a 4-stage cycle of the assessment process, namely (1) planning, (2) taking action, (3) observing, and (4) reflecting [29]. In other words, each cycle was comprised of Problem, Action Planning, Action Implementation, Observation, and Reflection [30].

The research was conducted for 4 months, from August to November 2019. The subjects of this research were 36 students from Class VIIA of MTsN 2 Makassar in English lesson. This school is located on Jl. Perintis Kemerdekaan $\mathrm{Km} 15$ Makassar, Indonesia. This research was given permission by both the school party and the families of the sample students. A variety of methods was employed maximally for the subjects of this research to provide an opportunity to obtain the data referring to it.

In this research, the students were asked to observe objects in form of images taken from the textbooks owned by the students and teachers in the classroom learning. The data were then collected through two instruments, namely test and non-test instruments. The former instrument further consisted of 2 types, namely pre-test, and post-test. The pre-test was used to determine the level of initial ability of students related to concepts or materials in English. It was conducted before the implementation of the OBL method and carried out at the beginning of each cycle. On the other hand, the post-test was intended to assess their ability after the application of the OBL method using the sheet with the same questions given in the pre-test.

The non-test instrument used an observation sheet to determine students' responses, interests, and behavior in English lesson and detect their unusual symptoms in the observation approach. There were four aspects which were involved in the non-test instrument, namely Visual Activities (students paid attention to the teacher's explanation), Oral Activities (students asked and answered questions and responded to questions and answers), Emotional Activities (students did tasks individually or in group), and Mental Activities (students analyzed problems or tasks in the activity sheet given by the teacher).

The data were analyzed using a descriptive analytic method. In this regard, the quantitative data were obtained from the tests and were processed with percentage descriptions. The value of percentage was calculated by dividing the cumulative value by the number of respondents and multiplied by $100 \%$ [29]. On the other side, the qualitative data were collected from a number of observations and journals and sorted out according to the aspects being examined. The quantitative and qualitative data were then linked and used as a basis for describing the successful application of the OBL method [27].

This research was carried out in three cycles without the existance of reflection, which is included in the analysis and assessment of the auction process. The first cycle aimed to determine the level of understanding of the material "Isn't It Good", the second cycle was carried out to find out the level of comprehension of the concept of "You can do it", and the third cycle was to figure out the level of mastery for the concept of "Put on Life Jacket, Please." Then, the observation approaches used the calculation which were expressed by both score and percentage for students' activities, with 1 standing for less (5-25\%), 2 for enough (26-50\%), 3 for good $(51-75 \%)$, and 4 for very good $(>75 \%)$.

\section{Findings}

The findings of the research are divided into several phases, namely:

\subsection{Planning Phase of Cycle I, II, and III}

In this phase, the researcher prepared the research instruments, namely the observation sheet for the students and the teacher regarding the learning activities, the worksheets for each meeting, and the pre-test and post-test questions. The lesson plan was discussed and compiled together with the teacher, following the curriculum objectives set in MTsN 2 Makassar. 


\subsection{Implementation Phase of Cycle I, II, and III}

Each cycle consisted of 2 meetings (45 minutes each) and applied the Observation-Based Learning (OBL) method. In Cycle I and Cycle II, 2 out of 26 students were absent, so the total number of attendees was 34 students. In Cycle III, all students attended the class. The material discussed in the first cycle was Unit 3 "Isn't It Good". This unit has 3 outputs: 1) identify and use expressions to ask for an opinion, 2) identify and use expressions to give an opinion, and 3) identify and express responses to an opinion. The material in Cycle II was Unit 4 "You can do it", which aims to: 1) identify and use expressions to ask about the ability to do something, 2) identify and use expressions to state the ability to do something, 3 ) identify and use expressions to ask about willingness to do something, 4) identify and use expressions to state unwillingness to do something, and 5) act out a dialogue expressing ability and willingness to do something. In Cycle III, the material was Unit 5 "Put on the Life Jacket, Please", consisting of 3 outputs, namely: 1) identify and use expressions to give instructions/commands, 2) Identify and use expressions to respond to an instruction/command, 3)identify and use expressions for prohibiting someone from doing something. The materials used were sourced from the worksheets and images of the textbooks and prepared in Microsoft PowerPoint, Pre-Test, and Post-Test.

\subsection{Observation Phase of Cycle I, II and III}

Each cycle was composed of 2 meetings. Based on the observation in Cycle I, in the visual aspect, 29 students presented their interest in the learning activity. This was indicated by their body movements; they actively raised their hands during the lessons. As in the oral aspect, 7 students in the first meeting and 11 students in the second meeting showed their interest by having discussion with the teacher and their classmates actively. In the emotional aspect, 26 students in the first and second meetings showed their enthusiasm in attending the class. This was seen from their feedbacks; they actively asked and answered questions during the lesson. Lastly, in the mental aspect, 12 students in the first and second meetings showed good mentality. Their excitement and spirit were seen in discussions.

Furthermore, in the visual aspect, 32 students presented their interest in learning the materials during the lesson in the first and second meetings of Cycle II. In the oral aspect, 15 students in the first meeting and 27 students in the second one were enthusiastic about participating in the lesson. Meanwhile, in the emotional aspect, 32 students in the first and second meetings showed signs of improvement. Finally, in the mental aspect, there were 32 students in the first and second meetings who showed their enthusiasm in participating in the lesson.

In Cycle III, 34 students in the first and second meetings showed their progress in the visual aspect. They were very enthusiastic in raising their hands during discussions and answering or asking questions. Furthermore, there was also an increase in the oral aspect where 28 students in the first meeting and 31 students in the second one built up their interest in the lesson. As in the emotional aspect, 32 students in the first and second meetings increasingly showed their excitement during the lesson. In addition, there were 32 students in the first meeting and 30 students in the second one who showed their improvement in the mental aspect.

The observations applying the OBL method in the three cycles were also carried out qualitatively. The results of the assessments were expressed at an ordinal scale, with 4 standing for very good, 3 for good, 2 for good enough, and 1 for less good. First, in Cycle I the visual aspect of the first and second meetings was rated 4. Furthermore, the oral aspect scored 2 for the first meeting and 3 for the second one. The emotional aspect of the first and second meetings both scored 4. Meanwhile, the mental aspect of the first and second meetings stood at 3 .

In Cycle II, the visual aspect was scored 4 for both meetings. The oral aspect scored 3 for the first meeting, while for the second meeting, it was rated 4. Furthermore, the emotional aspect and mental aspect both scored 4 for the first and second meetings.

As regards with Cycle III, which was the last cycle, all aspects led to excellent results, both for the first and second meetings. These results revealed that the OBL method brought a positive impact on the students.

After the data was collection, the percentage of the average score of each cycle was made in accordance with the formula in the research design. Each cycle was further given the percentage and the average score for each of its aspects. The results revealed that the average scores in Cycle I, Cycle II, and Cycle III for the four aspects (visual, oral, emotional, and mental) were $53.81 \%, 81.24 \%$, and $88.4 \%$ respectively.

\subsection{Pre-Test and Post-Test Assessment of the Research Object}

In each cycle, pre-test and post-test were carried out to measure changes that existed before and after the implementation of the OBL method. Throughout the three cycles, the pre-test and post-test had been carried out three times each. The results showed that the pre-test and post-test mean scores in Cycle I were 46.11 and 62.77 respectively. In Cycle II, the pre-test and post-test mean scores were 65.97 and 80.13 respectively. Finally, the pre-test and post-test mean scores in Cycle III were 75.55 and 86.8 , respectively.

Based on the results, there was an increase in the average scores of the pre-test and post-test. The upward tren also applied for all of the cycles. There was an increase in the average score by 16.66 in the first cycle, and by 14.16 in the second one. Furthermore, in the third 
cycle, the average score increased by 11.25 . It showed that the learning process of the OBL method was proven to increase the learning interest and achievement of the research objects, namely the eighth-grade students of MTsN 2 Makassar.

\subsection{Reflection Phase of Cycle I, II and III}

After the observation was carried out, the next phase was the reflection phase. The researchers had reflected on the research objects in each cycle and made important notes to improve the next cycle. The reflection processes in Cycles I, II, and III were by identifying deficiencies and making improvement. In this phase, the researchers identified the deficiencies of the students and then adopted the OBL method in the learning process. In the end of each cycle, some notes were taken about the process. Those notes were subsequently developed and implemented as the improvement plan for the next cycle. The results of the reflection phase are as follow:

\subsubsection{The Deficiencies of Cycle I}

At the beginning of the learning activities, some students were silent and confused as the OBL method was relatively new for them. The ability of the average students to ask and answer some questions was quite low. This was reflected by the number of the students participating actively in the lesson. Besides, the students felt hesitant or shy to ask questions or respond to the class. Some of them were even unwilling to ask despite the fact that they did not understand the topic being discussed. Additionally, they looked so reluctant to show their individual works in front of the class, and they only relied on the group. Based on the deficiencies seen in Cycle I, the improvement plans for the next cycle were as follows. First, focus on the learning objectives and steps. Second, direct the students to concentrate more on reading the textbooks distributed to them and to pay attention (observe) more closely to the existing images to better understand the materials and then be able to answer the questions listed. Third, give rewards (plus point) to the students who raise their hands to answer the questions asked by the teacher. Fourth, encourage the students to ask when they have not understood the material yet. Fifth, invite one student from each group to ask and answer some questions.

\subsubsection{The Deficiencies of Cycle II}

Initially, the students' oral and visual abilities were still low. However, their ability to ask and answer questions had begun to increase. It was seen from the increased number of the active students. Then, the students who were hesitant to give oral and written responses had gained a little courage to speak up even though they might be wrong. Most students raised their hands to ask and answer questions or respond. In addition, some students had no doubt in expressing the answers they had prepared and answering questions from their classmates. Based on the deficiencies of Cycle II, the improvement plans for the next cycle were as follows. First, focus on the class management, including the arrangement of tables and chairs to prevent the students to always glance out of the classroom since it would break their concentration. Second, direct the students to concentrate more in reading the textbooks, paying attention (observing) the existing images, and answering the questions listed (The same improvement plan as in Cycle I). Third, continue to encourage the students. Fourth, provide opportunities for the students to use their creativity in making sentences from the existing image. Fifth, ask one student from each group to ask and answer questions.

\subsubsection{The deficiencies of Cycle III}

As the third cycle began, the students had started to be more enthusiastic. Second, the students showed their passion for competition as they competed with one another in raising their hands to answer each question. Third, they continued to strive for the best score. Fourth, they still looked doubtful of responding to questions. Fifth, more than $50 \%$ of the students were enthusiastic about learning English by showing their creativity or finding something new. For example, they were able to make sentences using new vocabularies that they had learned. Based on the deficiencies of Cycle III, the improvement plans were as follows. First, concentrate on the learning steps, outcomes and resources that the students had had. Second, direct the students to concentrate more on reading the materials using mini dictionaries as to determine the answers to the objects listed on the prepared questions. Third, give rewards in form of plus point to those who have the courage to raise their hands to answer the questions asked by the teacher. Fourth, continue to reward the students who did their best during the lesson and encourage those who had not achieved their optimal outcomes yet. Fifth, continue to provide support by recommending the other learning resources and textbooks available at school or in the library.

\section{Discussions}

\subsection{Observation Results of Students' Learning Activities in Cycles I, II and III}

The learning activities of the students were analyzed based on the observation sheet during the implementation of the OBL method, whose purpose was to determine all aspects of the learning process of English lesson in percentage. The observation sheet was meant to analyze each action at the end of the cycle. The observation recapitulation of the students' learning activities can be seen in the following table. 
Observation Results on Students Learning Activities Cycles I, II and III



Figure 1. Observation Results of Students' Learning Activities in Cycles I, II, and III

The average result for the first cycle was relatively low at $53.81 \%$. This percentage was obtained from the scores on the observation sheet of the students' learning activities. However, the average result of the students' learning activities in English lesson increased to $81.24 \%$ in Cycle II. The third cycle obtained the highest scores individually, and the average value reached $88.4 \%$. It proves that Observation-Based Learning (OBL) could increase the students' learning activities in English lesson.

Figure 1 above shows a positive outcome for each aspect of the assessments, namely visual, oral, emotional, and mental aspects. The first activity to be assessed was visual. The visual activities observed were reading, looking at pictures, observing experiments, demonstrations, and exhibitions, paying attention to the teacher's explanation carefully (focusing on the lesson), and observing the classmates' activities. In this cycle, the students had started to pay attention and have competitive power, such as hands-on discussion sessions (Bilgin, 2006). The results of this study indicated that the visual aspect of the students increased after the application of the OBL method. This means that this method could increase the students' confidence and enthusiasm for learning.

The second aspect assessed was the oral ability of the research objects. What is considered as an oral aspect is an oral activity of expressing a fact or principle, linking an event, asking a question, giving advice, expressing an opinion, doing interview, having discussion, and interrupting. In Cycle I, the students' verbal ability was extremely low, at $24.99 \%$. However, the percentage increased in Cycle II, by standing at $58.33 \%$. This figure continued to rise to $81.9 \%$ in Cycle III. This indicated that the OBL method succeeded in improving the oral abilities of the research subjects in expressing opinions, discussing, reasoning, and communicating verbally to their peers or teacher in the class. Based on the observation, it can be concluded that the oral aspect has a positive impact on the students' independence. In addition, the students also begin to gain and even increase their self-confidence.

The third aspect assessed was the emotional ability. It was almost similar to the oral aspect, but the indicator was the students' courage on the emotional aspect. The results revealed an increase in the emotional ability from Cycle I to Cycle II by $12.5 \%$. This percentage increased even further in Cycle III by reaching its peak of $88.9 \%$. The sharp increase occurred after the OBL method was implemented in the class.

The last aspect was the mental ability. The indicators used were mental activities, including pondering, remembering, solving problems, analyzing factors, looking at relationships, and making decisions. After the adoption of the OBL method, there was a drastic increase from Cycle I to Cycle II, by $55.55 \%$. Then, the percentage increased slightly by $0.02 \%$ in Cycle III. The mental aspect had the most significant changes among all aspects of the research subjects. This means that there was a positive outcome in the mental abilities of the research objects after the implementation of the OBL method.

\subsection{Comparison of Learning Outcomes in Cycle I, II and III}

The pre-test and post-test of this study were carried out in order to determine the percentage of changes that occurred during the implementation of the OBL method in the class. The following is an overview of the changes in Cycle I, II, and III.

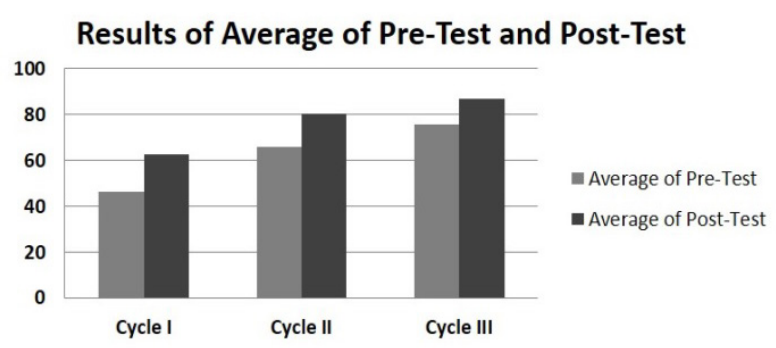

Figure 2. Results of Average Scores of Pre-Test and Post-Test

As seen in Figure 2, there was an increase in the average learning outcomes of the students. In Cycle I, the average score was accounted for 62.77. This figure then rose significantly to 80.13 in Cycle II and reached a peak of 86.8 in Cycle III. This indicated that the students' learning outcomes increased sharply from Cycle I to Cycle III.

Based on the findings, the increased scores of the pre-test and post-test were closely adherent to the application of the OBL method by the English teacher (the researcher) to have a significant and influential instructional impact. Therefore, it can be concluded that the implementation of the OBL method in English lesson was beneficial to the research subjects, namely the eighth-grade students at MTsN 2 Makassar.

\subsection{Obstacles and Supporting Factors in the Application of the OBL Method}

In this research, during the implementation of the OBL 
method on the research objects, there had been positive changes from 4 aspects of assessments, namely visual, oral, emotional, and mental. In addition to the data presented earlier, there was also an increase in the spirit and enthusiasm of the research objects in attending English lesson.

However, there were a number of obstacles appearing in the application of the OBL method.

1. Internal factors of the students. Some students had weak learning abilities, so they were relatively slow to achieve changes or improvement in the aspects of their learning activities and outcomes.

2. Inadequate facilities. The availability of English textbooks and related resources remained insufficient.

3. Limited time. A cycle consisted of only 2 meetings (45 minutes each).

4. Class management. The table and chairs had not been optimally arranged.

5. The total number of students. There were so many students in the classroom.

On the other hand, there were supporting factors in the implementation of the OBL method.

1. The professionalism of the teacher in understanding and mastering the curriculum and the lesson.

2. The diversity of the students' characters, which enabled the researchers to observe them more easily in the class.

\section{Conclusions}

The results of this research revealed that the Observation-Based Learning (OBL) method could shift the learning paradigm from subject-oriented and teacher-centered to student-centered. Despite being applied to the eighth-grade students of MTsN 2 Makassar in English subject, the designated learning method can also be implemented in any other subjects in all levels of education. In addition, the OBL method has an instructional effect. This is indicated by the increased average post-test scores of each cycle. Besides, the application of OBL also has a nurturing effect. This can be seen from the observation phase, in which the students expressed their curiosity, discipline, motivation, flexibility, and enthusiasm through the visual, oral, emotional, and mental activities. Therefore, the application of OBL is proven to be effective in increasing the students' learning creativity. In the application of OBL method, the students can examine and learn about the phenomena given, thus allowing them to make conclusions based on their observations.

The implementation of the OBL method can benefit not only primary and secondary education but also tertiary education. In this regard, teachers and lecturers need to adjust the presented materials with learning objectives, available media and facilities, and student characteristics.
The OBL method has a significant impact on both teachers and students to increase their motivation, enthusiasm, and creativity in learning. Therefore, the young generation in the future will be able to make great contribution to the nation, state, and religion.

\section{Acknowledgments}

This research was funded by the Development and Research Institute (LP2S) of Universitas Muslim Indonesia (Muslim University of Indonesia).

\section{REFERENCES}

[1] Muganga, L., \& Ssenkusu, P, Teacher-Centered vs. Student-Centered, Cultural and Pedagogical Inquiry, Vol. 11, No. 2, 16-40, 2019.

[2] Dwidienawati, D., \& Gandasari, D, Understanding Indonesia's generation $\mathrm{Z}$, International Journal of Engineering and Technology (UAE), Vol. 7, No. 3, 250-252. 2018.

[3] Sleicher, A, Insights and interpretations (Issue 5), 2018.

[4] Imroatus Solikhah, T. B, Investigating the Learning Outcomes of an INQF-Based English Language Teaching Curriculum in Indonesia, Journal Of Social Studies Education Research, Vol. 10, No. 4, 153-175, 2019.

[5] McLeod, Observation methods, simply psychology, Online available from .https://www.simplypsychology.org/observa tion.html.

[6] TIMSS, International Science Achievement for Eight Grade, 2015.

[7] Gedrovics, J, Interest In Science As The Key To Successful Science Studies Or - Awaken The Interest, Develop And Strengthen It!, Journal of Baltic Science Education, Vol. 6, No. 2, 2007.

[8] Zhuojun, W., \& Hualing, H., National Identity in the Era of Globalization: Crisis and Reconstruction. Social Sciences in China, Vol. 35, No. 2, 139-154, 2014.

[9] Santoso, I, Pembelajaran Bahasa Asing di Indonesia : Antara Globalisasi dan Hegemoni, Bahasa \& Sastra, Vol. 14, No. 1, $1-11,2014$.

[10] Pehkonen, E, The State-of-Art in Mathematical Creativity, International Journal on Mathematics Education, Vol. 29, No. 3, 63-67, 2014.

[11] Öhrstedt, M., \& Scheja, M, Targeting efficient studying first-semester psychology students' experiences, Educational Research, Vol. 60, No. 1, 80-96. 2018.

[12] Maulina, P. H., \& Puspita, L, 5M (Mengamati, Menanya, Mencoba, Menalar, dan Membentuk Jejaring), Vol. 5, No.2, 132-139, 2015.

[13] Kearney, M. (2004), Classroom Use of 
Multimedia-Supported Predict-Observe-Explain Tasks in a Social Constructivist Learning Environment, Research in Science Education, Vol. 34, No. 4, 427-453, 2004.

[14] Turner, R. C., Keiffer, E. A., \& Salamo, G. J., Observing Inquiry-Based Learning Environments Using the Scholastic Inquiry Observation Instrument, International Journal of Science and Mathematics Education, Vol. 16, No. 8, 14551478, 2018.

[15] Groenendijk, T., Janssen, T., Rijlaarsdam, G., \& van den Bergh, H., The effect of observational learning on students' performance, processes, and motivation in two creative domains, British Journal of Educational Psychology, Vol. 83, No. 1, 3-28, 2013.

[16] Siddiqui, N., Gorard, S., \& See, B. H, The importance of process evaluation for randomised control trials in education, Educational Research, Vol. 60, No. 3, 357-370, 2018.

[17] Asghar, A., Canadian and Pakistani Muslim teachers' perceptions of evolutionary science and evolution education, Evolution: Education and Outreach, Vol. 6, No. 1, 10, 2013.

[18] Sui, A., \& Leung, M., An Effective Learning Model to Support People Development: The Emerging Approach of The Hong Kong Institute for Vocational Education, International Education Studies, Vol. 3, No. 4, 94-106, 2010 .

[19] Bandura, A, The Evolution of Social Cognitive Theory. In Great Minds in Management, 9-35, 2005.

[20] Kurz, D. E, The use of participant observation in evaluation research, Evaluation and Program Planning, Vol. 6, No. 2, 93-102, 1983.

[21] Treffinger, D., Isaksen, S., \& Dorval, K, Creative Problem Solving (CPS Version 6.1 ${ }^{\mathrm{TM}}$ ) A Contemporary Framework for Managing Change, 2003.

[22] Alanazi, F. H., The Perceptions of Students in Secondary School in Regard to Evolution-Based Teaching: Acceptance and Evolution Learning Experiences-The Kingdom of
Saudi Arabia, Research in Science Education, 2019.

[23] Fettahlıŏlu, P., \& Aydoğdu, M, Developing Environmentally Responsible Behaviours Through the Implementation of Argumentation- and Problem-Based Learning Models, Research in Science Education, Vol .50, 987-1025, 2018

[24] Syah, M. N. S., English Education For Islamic University in Indonesia: Status and Challenge, Qudus International Journal of Islamic Studies, Vol. 3, No. 2, 168-191, 2015.

[25] Ilyasin, M, Exploring Excellency-Based Curriculum for Indonesian Primary Schools in Relation to the Social Community Environment, Journal of Social Studies Education Research, Vol. 10, No. 4, 246-265, 2019.

[26] Syae Purrohman, P., Classroom Action Research Alternative Research Activity for Teachers, 2011.

[27] Neuman, W. L., Social Research Methods: Qualitative and Quantitative Approaches In Teaching Sociology (Seventh Ed, Vol. 30, Issue 3). Pearson Custom Library, New York, 2002.

[28] Chan, S., The contribution of observation to apprentices' learning, Journal of Vocational Education \& Training, Vol. 67, No. 4, 442-459, 2015.

[29] Kemmis, S., McTaggart, R., \& Nixon, R., The action research planner: Doing critical participatory action research, Springer Science \& Business Media, 2013.

[30] Amri, Z., Classroom Action Research And Lesson Study: How Do They Work For Lecturers And High School English Teachers. SELT, Vol. 1, 260-266, 2013.

[31] Bilgin, I., The Effects Of Hands-On Activities Incorporating A Cooperative Learning Approach On Eight Grade Students' science Process Skills And Attitudes Toward Science, Journal of Baltic Science Education, Vol. 5, No. 1, 27-37, 2006. 